\title{
Green Banking and Infrastructure Project Financing for Sustainable Development
}

\author{
Arinal Fashli ${ }^{1}$, Herdis Herdiansyah ${ }^{1 *}$, and Putri A Saragi ${ }^{1}$ \\ ${ }^{1}$ School of Environmental Science, Universitas Indonesia, Salemba, Indonesia
}

\begin{abstract}
Indonesia already has policies that pay attention to environmental aspects so that the development can keep running by maintaining the natural conditions. One of the policies that have been made is green banking. The green banking policy requires the support of stakeholders who have a role as an enforcer. This study uses a quantitative approach to measure the implementation of funds used by banks in the financing of industrial projects. The database is based on the Sustainable Equity and Responsible Investment (SRI) index -KEHATI, one of the indices that the indicator of stock price movement in Indonesia Stock Exchange (BEI), but focus on banking data practicing green banking system. The result of this study shows that the bank has a responsibility to the environmental risks of the project to be run by the company where the investment funds or lending of the bank. The green banking policy requires the support of stakeholders who have a role as an enforcer. Stakeholders in green banking are groups of people or individuals who have an essential part to achieve goals, and Sustainable development can be realized well if this policy is implemented, not just a formal requirement in following the current international trend.
\end{abstract}

Keywords: Green banking; Infrastructure; Project Financing; Industry; Sustainable Development.

\section{Introduction}

Indonesia is a developing country that aims to become a developed country. Soemarwoto (1983) The development seeks to improve the quality of the economy to meet the needs and quality of life of the community. Environmental issues are important to discuss, especially when linked with the implementation of national development. He said "development aims to improve people's lives and welfare, including the quality of community life because it can be defined as the level of basic of fulfillment, basic needs development needs of society. The basic needs are divided into three parts: basic needs for biological survival, basic needs for humanity, survival, and freedom of choice. Many studies show that the basic needs for the majority of our society are not yet meet, for example, food, clean water, education, employment, and housing have not been available enough, despite many improvements since the development of more than 30 years ago, for which development still has to continue" [1]. According to UNEP, Sustainable development is one of application of the concept of the green economy which means a development model to prevent increasing of greenhouse gas emissions and to overcome climate change [2].

The existence of a green economy concept within a company is not just a matter of corporate impact, but where funding for corporations comes from. Because of the idea of green banking that guides banks in all activities, including the provision of corporate credit financing. Banks can help with the promotion of financial products to achieve the target benefits to the environment [3]. Therefore, with the concept of green banking will be able to help solve environmental problems one level ahead. The banking sector plays an important role in maintaining economic growth through economic and financial development projects [4]. Lindlein (2012) admitted that the increase in profit is still the focus of the bank, only a few banks offer green financing products so that the product has not been able to keep up with market progress [5]. The main problem in greening the banking sector needs particular attention to support sustainable development.

The world commission on environment and development defines that sustainable development is

\footnotetext{
*Corresponding author: herdis@ui.ac.id
} 
development aimed at meeting the needs of future generations. Soemarwoto (1983) "the requirements for sustainable development are not only physical aspects, which do not damage the ecosystems we live in, but also the fair outcomes and development costs between countries and between groups within a country." [6]. Development without impact to the environment is impossible, so that the financial aspects of development need to contribute to the environment.

Financial institutions play an essential role in environmental financing to achieve sustainable development [7]. Köhn (2012) indicates that financial markets have a vital role for the tremendous economic development and can also be essential development agents [8]. Bahl (2017) explains that green banking is an environmentally sound banking practice by banks in the region of its operations by promoting its banking activities and taking into account the interests of Stakeholders [9].

The concept of green banking has been developed to reduce adverse environmental impacts, either directly or indirectly. By adopting the principle of sustainable development that ensures development, green banking has a balance on three points of view (Triple Bottom Line); such as Profit, People, and the Planet [10]. So it can be concluded that green banking is a banking regulatory policy that should pay attention to the direct impact of bank operations and the indirect impact of funds invested by understanding the balance of the three perspectives of sustainability development.

The idea of green banking emerged from the "Equator Principle" in 2002. The basic framework of social management and environmental risks in project financing has been formulated and adopted from the Equator Principles (EP) on June 4, 2003 by 10 leading banks from 7 countries in the world.[11]. Since 2006 the original principles have been improved and strengthened. So as nearly 70 banks and financial institutions have imposed total capital costs above USD 10 million of $85 \%$ of the volume of global project funding.[12]. Because the principles apply, every bank in the countries that involved in the "Equator Principle" has brought and supports environmental issues. We need to be aware that bank activities have a direct and indirect impact. The immediate effects of bank operations, such as paper use, excessive electricity, and transportation, while indirect impacts. Thus, banks must offer green products on the market and examine the effects of their product offerings on society on environmental and social issues [13]. However, currently in Indonesia the discussion of green banking regulations is still not completed. The results of research conducted in Vietnam by Linh and Anh (2017), the most significant and urgent solution is to determine the set of criteria for the assessment of environmental and social risk in credit assessment [14].

\subsection{Stakeholder in green banking}

The interrelated cooperation between stakeholders in the green banking policy will assist in realizing green banking objectives of environmental sustainability. Realizing the sustainability of banking in this area is needed the role of legislation and stakeholders [15]. Bank Indonesia as the representative of the government in making banking regulations should produce a clear policy, so there is no overlap and weak policy. The Financial Services Authority (OJK) serves as the supervisor of bank services in every banking activity especially in operations and funding in its business branches. Commercial banks are responsible for implementing green banking policies and complying with established rules and also conducting their activities following banking regulatory corridors.

Stakeholders are a group of people who have an essential role to achieve goals. Indonesia has several institutions as stakeholders in this scope, namely the Financial Services Authority (OJK), Bank Indonesia, Commercial Banks, and Companies. Stakeholder roles and cooperation among stakeholders are essential for achieving environmental sustainability objectives.

Table 1. List of Stakeholder on Green Banking (Adapted from Freeman (2006)) [16]

\begin{tabular}{|l|l|l|}
\hline No & Internal & External \\
\hline 1 & Shareholders & $\begin{array}{l}\text { Bank of } \\
\text { Indonesia }\end{array}$ \\
\hline 2 & Employees & $\begin{array}{l}\text { Otoritas Jasa } \\
\text { Keuangan/OJK }\end{array}$ \\
\hline 3 & Manager & Customer \\
\hline
\end{tabular}

In table 1 there is list of stakeholder adapted from Freeman (2006) theory of stakeholder. Separation of this stakeholder means differentiation of function and effect to the application of Green Banking Regulation. Fontaine (2006) said to develop business strategy, a stakeholder approach is needed to pay attention to the active management of the business environment, relationships and the promotion of common interests [17]. Stakeholder Engagement quality was one of the factors for environmental impact assessment [18].

\section{Material and Method}

This study uses a quantitative approach to measure the implementation of funds used by banks in the financing of industrial projects. The database is based on the Sustainable Equity and Responsible Investment (SRI) index -KEHATI, one of the indices that the indicator of stock price movement in Indonesia Stock Exchange (BEI), but focus on banking data practicing green banking system. This index is an initiation of environmental NGOs and cooperates with the Indonesian stock exchange authority that calculates the principles of sustainability, finance and good 
governance, and environmental awareness as a benchmark. Hence the principles of production are done utilizing environmental management sustainable.

\section{Results and Discussion}

Based on the research results obtained as follows.

Table 2. List of Funding Programs and Banks [19], [20]

\begin{tabular}{|c|l|c|c|c|}
\hline No & $\begin{array}{c}\text { Funded } \\
\text { Program }\end{array}$ & $\begin{array}{c}\text { Funding } \\
\text { Bank }\end{array}$ & Quantity & Amount \\
\hline 1 & PLTB & $\begin{array}{c}\text { Bank } \\
\text { Mandiri }\end{array}$ & $26,3 \mathrm{MW}$ & $\begin{array}{l}41,3 \\
\text { Million } \\
\text { US\$ }\end{array}$ \\
\hline 2 & PLTPB & BRI & $800 \mathrm{MW}$ & $\begin{array}{c}127 \\
\text { billion } \\
\text { IDR }\end{array}$ \\
\hline 3 & PLTPH & BNI & $2 \mathrm{KW}$ & - \\
\hline 4 & BiRu & BJB & - & $\begin{array}{c}6,79 \\
\text { billion } \\
\text { IDR }\end{array}$ \\
\hline 5 & $\begin{array}{l}\text { Environment } \\
\text { (CSR) }\end{array}$ & & & \\
\end{tabular}

Almost all state-owned and private banks in Indonesia have adopted green banking in every policy. However, not all banks describe it in a detail program plan. Thus, how the sustainability of its implementation in this green banking development effort cannot be monitored precisely. Data in 2013 shows that investment loans and working capital channeled by the national banking almost reached 2400 trillion rupiah, of which $67 \%$ of working capital loans. The market share of investment credit and working capital credit from ten banks with the most considerable assets eroded about 54.5 percent by the end of 2013. Five years earlier, it was still above 59 percent [21]. There is an example of a green banking regulation issued by the China Banking Regulatory Commission (CBRC) that is, the Bank must strengthen due diligence and also the Bank must determine the environmental and social risk thoroughness coverage based on the sector and the client's or project's geographic features, to ensure a comprehensive, and in detail, then if necessary, the bank may seek the support of qualified and independent third parties and relevant regulators [22].

The Bank mainly carries out the role of intermediation within the framework of nationbuilding. The intermediary function played by the bank is manifested in the channeling of loan funds to the business community [24]. Therefore, banks have a central role in accommodating the costs of environmental management and protection as a form of integration of infrastructure, human resources, economic and environmental development. Putri, Amrina, and Astria (2017) indicate that the application of green banking is also affected by the knowledge of green banking for the community that is influenced by the promotion and publication system conducted by the bank. Research conducted by them shows that there are still many banking services that do not know about banking rules [25]. The term sustainability control will not be realized if there is no control. Therefore the green banking policy becomes more assertive to be applied to every bank activity, both in its operation and also it is funding. Thus, there is a need for secure interconnection and monitoring by Stakeholders to achieve the goal of green banking, namely the sustainability of synergistic efforts and nature [26] [27]. Funding that pays attention to environmental aspects will ultimately make the process of developing environmentally friendly. Now gradually many projects, especially in the energy sector that strictly implement the principles of environmental protection to be funded [28].

Table 3. SRIKEHATI Index Statistics Source data by Septiani, 2017 [23]

\begin{tabular}{|c|c|c|c|c|c|c|c|}
\hline $\begin{array}{c}\text { Before SRI } \\
\text { 2007-2009 }\end{array}$ & $\begin{array}{c}\text { Price of } \\
\text { Securities }\end{array}$ & GCG & NPL & LDR & ROE & NIM & CAR \\
\hline Mean & 4026,56 & 1,447 & 0,020 & 0,673 & 0,219 & 0,076 & 0,163 \\
\hline Median & 3767,04 & 1,35 & 0,017 & 0,641 & 0,221 & 0,064 & 0,157 \\
\hline $\begin{array}{c}\text { Standard } \\
\text { Deviation }\end{array}$ & 1887,63 & 0,271 & 0,014 & 0,146 & 0,094 & 0,024 & 0,027 \\
\hline Minimum & 1113,23 & 1,1 & 0,004 & 0,436 & 0,0803 & 0,0499 & 0,1318 \\
\hline Maximum & 7149,94 & 2,05 & 0,045 & 0,888 & 0,3522 & 0,111 & 0,211 \\
\hline $\begin{array}{c}\text { After SRI 2010- } \\
\text { 2012 }\end{array}$ & $\begin{array}{c}\text { Price of } \\
\text { Securities }\end{array}$ & GCG & NPL & LDR & ROE & NIM & CAR \\
\hline Mean & 6011,56 & 1,138 & 0,013 & 0,766 & 0,272 & 0,071 & 0,157 \\
\hline Median & 5831,37 & 1,31 & 0,008 & 0,7517 & 0,244 & 0,059 & 0,153 \\
\hline $\begin{array}{c}\text { Standard } \\
\text { Deviation }\end{array}$ & 1716,69 & 0,143 & 0,010 & 0,128 & 0,092 & 0,020 & 0,020 \\
\hline Minimum & 2756,73 & 1,08 & 0,004 & 0,552 & 0,162 & 0,051 & 0,127 \\
\hline Maximum & 9282,69 & 1,5 & 0,03 & 1,006 & 0,4383 & 0,1077 & 0,189 \\
\hline
\end{tabular}




\section{Conclusion}

Implementation of green banking policy in Indonesia has been started since 2010. Almost all banks in Indonesia have implemented the policy to support and sustain the nation's development in various sectors. The fundamental principle of the application of Green Banking is one of the funding synergy efforts that focus not only the profit and sustainability of the business but also the viability of the environment as the basis of corporate responsibility. In the long run, the trend will increase the number of increasingly stringent banking portfolios in funding the corporations and calling for corporate responsibility in ensuring that the financed enterprises enter the aspects of environmental protection and sustainability. The results of this study can be used as a references to develop green banking policies in the future and encourage all companies to incorporate aspects of environmental protection and sustainability as an effort to lower carbon.

This research is funded by the Grant of Indexed International Publication for Final Project of Students/Publikasi Terindeks Internasional Untuk Tugas Akhir Mahasiswa (PITTA) Universitas Indonesia 2018 with contract number 2578/UN.R3.1/HKP.05.00/2018 and special acknowledgments to Priyaji Agung Pambudi who helped analyze the data.

\section{Reference}

1. Soemarwoto, O. Djambatan, (1983).

2. Panjaitan, L., Penebar Plus, (2015).

3. Pfeiffer K., M. Adler, and C. Kreiss, Springer Berlin Heidelberg, 241-246 (2012).

4. Linh, D., H., and Anh V., T. Econ. Ann.,. 165, 5-6. 143-151, (2017).

5. Lindlein, P. Springer Berlin Heidelberg, 1-30 (2012).

6. Soemarwoto, O. Djambatan, (1983).

7. Lindlein, P. Springer Berlin Heidelberg, 1-30 (2012).
8. Köhn, D., Springer Berlin Heidelberg, (2012).

9. Mehedi, S., 21, 2,1-20, (2017).

10. Putri, N. T., Amrina, E., and Astria, G., Lecture Notes in Engineering and Computer Science. 2228, 1, (2017).

11. Amalric, F., THe Equator Ppinciples: A Step Fowards Sustainability?,". 1, (2005).

12. Clements-Hunt, P. Springer Berlin Heidelberg, (2012)

13. Damanik, S. E., (Population Interaction, Environment and National Development Against Regional Development)". 1-4, (2016)

14. Linh, D., H., and Anh V., T. Econ. Ann., 165, 5-6, pp. 143-151. (2017).

15. Lindlein, P., Springer Berlin Heidelberg, 1-30, (2012)

16. Fontaine, C., "The Stakeholder Theory," Management,. 1,. 37-44, (2006).

17. Fontaine, C., "The Stakeholder Theory," Management, 1, December. 37-44, (2006).

18. Venturelli, A., Cosma, S., and Leopizzi, R., Corp. Soc. Responsib. Environ. Manag., (2018).

19. [Online]. ("Implementation of the Expanded Green Banking Concept," (2014)

20. Suryaman., and Suwandi, Y. W. Pros. SENTIA 2016, 8. 36-42, (2016).)

21. Budiantoro, S. Guarding Green Banking Indonesia Under the Framework of Sustainable Development)(2014).

22. CBRC,Available: http://www.cbrc.gov.cn/chinese/home/docDOC ReadView/127DE230BC31468B9329EFB01AF 78BD4.html.

23. Budiantoro, S. Guarding Green Banking Indonesia Under the Framework of Sustainable Development ) (2014).

24. Suryaman., and Suwandi, Y. W. Pros. SENTIA 2016,. 8,. 36-42, (2016).)

25. S. Mehedi, "Green Banking: A Case Study On Dutch-,. 21, 2,. 1-20, (2017).

26. ES Irianto, H Rosdiana, LF Sardjono, MRUD Tambuna, E3S Web of Conferences 52, 00012

27. Nuryadin. IOP Conf. Ser.: Earth Environ. Sci. 88. 012029, (2017) 